\title{
Preliminary Survey on Knowledge, Attitudes, and Practices about the COVID-19 Pandemic among Residents in North Central Nigeria
}

Elijah Edache Ehoche 1*®
Johnson Adejoh 2
Joseph Idoko ${ }^{3}$
Chijioke Madu 2
1Department of Biochemistry, Federal
University of Technology, Minna,
Minna, Niger State, Nigeria
2Department of Medical Biochemistry,
University of Abuja, Gwagwalada,
Abuja, Nigeria
3Department of Public Administration,
Benue State Polytechnic, Okpokwu,
Benue State, Nigeria
*email: elaijahee@gmail.com
Keywords:
COVID-19
Knowledge
Practice
North Central Nigeria

\begin{abstract}
A preliminary survey on the knowledge, attitude, and practice of the COVID-19 pandemic among residence in North Central Nigeria, was conducted. An anonymous electronic network sampling survey designed by e-survey was employed. The result showed that on the level of knowledge and practice, $76.83 \%$ opined that people may be sick for 1-14 days without developing the symptoms. On the viral transmission, $94.41 \%$ agreed that the transmission of the virus can be through direct contact with contaminated surfaces through eyes, nose, and mouth, as well as $78.35 \%$, responded that the virus doesn't penetrate the skin. More so $92.04 \%$ of the respondents showed that older and sick people are more vulnerable to the disease with $98.86 \%$ showing that the most common symptoms may include fever, tiredness, dry cough, and sometimes difficulty in breathing. Only $24.43 \%$ asserted that COVID-19 cannot be transmitted through social gatherings, going put often, making direct physical contact with people. Meanwhile, $21.02 \%$ showed COVID-19 is a punishment for immoral behavior. On the rate of the outbreak, $94.32 \%$ said it is scary. Only $55.11 \%$ asserted approval of the control approach by the government. However, $82.29 \%$ would agree with the response of the masses to government measures to control the spread. On the way forward, $98.87 \%$ advised the need for more research and $87.08 \%$ would approve of vaccination against the disease. This implies that the respondents have a good level of knowledge and practice about COVID-19 and necessary adjustments are needed to control or manage the spread of the pandemic.
\end{abstract}

Received: May 26th, 2020

Accepted: June 17th, 2020

Published: June 22nd, 2020

(c) 2020 Elijah Edache Ehoche, Johnson Adejoh, Joseph Idoko, Chijioke Madu. Published by Institute for Research and Community Services Universitas Muhammadiyah Palangkaraya. This is an Open Access article under the CC-BY-SA License (http://creativecommons.org/licenses/by-sa/4.0/). DOI: https:// doi.org/10.33084/ bjop.v3iSpecial-1.1413

\section{INTRODUCTION}

The novel coronavirus disease 2019 (COVID-19) is a disease that is caused by a new and severe type of coronavirus known as severe acute respiratory syndrome coronavirus 2 (SARS-CoV-2) (Li et al., 2020; Hafeez et al., 2020). Over 7 million people have been infected globally with over three hundred thousand deaths and counting as a result of COVID-19 infection which started unprecedentedly in December 2019 in the Wuhan district of China (Worldometer, 2020). In Africa,
95,482 cases are confirmed so far while in Nigeria; over six thousand people are being infected as of the time of compiling this report (European Centre for Disease Prevention and Control, 2020).

The viral infection has been said to be without cure creating a rapidly spreading pandemic (Andersen et al., 2020), while the peak is yet uncertain (Djalante et al., 2020). Researchers have been pulling from various pools of resources searching for ways to end the ravaging plague (Ebenhardt et al., 2020). Most treatment for the disease so far is largely based on the management of the symptoms 
pending on the strength of the immune system and or the presence of underlying infections or diseases (Felsenstein et al., 2020).

Nonetheless, it is not an overstatement that the pandemic has affected every aspect of the life of the world inhabitants. The devastating effects cut across humans of all ages, irrespective of their class, race, religion, and education to mention but a few (Bhagavathula et al., 2020). This happens in various ways as different individuals approach it from different perspectives depending on their knowledge, practice, and attitude. In Nigeria, for example, preventive efforts are being proscribed and enforced by the various authorities to curtail the level of spread of the plague, it has also brought along some consequences among the people across the various backgrounds (Olapegba et al., 2020).

Such a large effect could affect people's response to treatment, management, or control of the ravaging disease (Laviano, 2020). More so, it could also help authorities in managing the post-pandemic era until the world fully recovers as the pandemic has the potential of modifying world view as well as the culture of daily living. The study also supported Richards (2016), who opinion that knowledge among ordinary people about how to eliminate risks of contracting Ebola virus led to a rapid drop in mid-2015 in the number of cases of infection. It is therefore essential to investigate the knowledge, attitude, and practice on COVID-19. Based on this background and study, this research was conducted to find out about how knowledge, attitudes, and practices about the COVID-19 pandemic from residences in Nigeria, especially in the north-central part.

\section{MATERIALS AND METHODS}

\section{Preparation and participants}

In April 2020, we enrolled a familial cluster involving the COVID-19 survey to collect a database on an individual's perspective regarding the COVID-19 pandemic in northcentral Nigeria, a geopolitical region that comprises of states in the middle belt region of the country.

This cross-sectional survey used an anonymous online questionnaire to collect data from respondents. To effectively collect the data, a survey questionnaire containing 23 different questions, and their respective responses on the knowledge, attitude, and practice on the COVID-19 pandemic among Nigerians was developed. Potential respondents were purposively sent the link (https://www.esurveycreator.com/s/699e1dc) via various social media (Facebook, Whatsapp, Twitter, Instagram, and other posts) and asked to participate in an online survey. The link further redirects end-users (respondents) to Google Chrome, PHX Browser, and Opera for responses. A snowball sampling technique was employed to recruit more Nigerians living in the country's six geopolitical zones during the COVID-19 pandemic by encouraging those sent the link to kindly share with their contacts. The online survey ran during the second week of the lockdown in Nigeria (April $4^{\text {th }}$ to May $\left.16^{\text {th }}, 2020\right)$ and involved 204 respondents from different cities, towns, and villages in the stated region of the country.

The questionnaire was divided into four pages. In total there were 23 questions asked by participants, of which 7 were related to participant's biodata while 16 contained questions about participants' level of knowledge. The first three questions on page 1 reflect on the respondent's gender, age, and location. Questions on page 2 reflect on the occupation of the respondents, marital status, as well as the most used social media. Page 3 and 4 of the questionnaire reflect on questions regarding the respondent's income and how much they agree with certain statements on the COVID-19 pandemic. Some of the questions were weighed using different signs which further expressed the respondent's perspective towards 
the questions. For example, '--' was used for 'Not agreed', '-' was used for 'Barely agreed', '+' was used for 'Agreed', while ' ++ ' was used for 'Strongly agreed'. Below is a copy of the questionnaire containing different questions and expected responses were based on individual knowledge, attitude, and practice on the COVID-19 pandemic.

1. COVID-19 is a disease without a cure

2. COVID-19 is caused by the novel coronavirus

3. A healthy-looking person cannot contract the disease

4. People may be sick for 1-14 days without developing the symptoms

5. The transmission can be through direct contact with contaminated surfaces through eyes, nose, and mouth

6. The virus doesn't penetrate the skin

7. Older and sick people are more vulnerable to the disease

8. Most common symptoms may include fever, tiredness, dry cough and sometimes difficulty in breathing

9. Prevention of the disease may include the use of face mask, hand washing, social distancing, and selfisolation

10. COVID-19 cannot be transmitted through social gathering, going put often, making direct physical contacts with people

11. COVID-19 is a punishment for moral behavior

12. The rate or the outbreak is scary

13. The approach by the government in controlling the outbreak is satisfactory

14. How would you agree with the response of the masses to government measures?

15. More research towards a possible cure, control or prevention is advised

16. If they were some vaccine, how would approve vaccination?

\section{Procedure}

Because of the Nigerian Government's social distance rules and curfew/lockdown enforcement, physical interaction was not possible, so online promotion of the survey was done and existing study participants were urged to send the web link of the survey to potential respondents. They completed the questionnaires hosted a one-survey online survey platform. Participation was completely consensual, anonymous, and voluntary, and informed consent was obtained from all respondents.

\section{Statistical analysis}

Descriptive statistics were used for respondents' sociodemographic characteristics and knowledge about COVID-19. Upon completion of the survey, the respondents submit their responses by simply click on the "SUBMIT" cascade/dialog beneath the questionnaire. The responses from each of the respondents were captured by the e-survey software and analyzed immediately. The analyzed data appeared in the bar chart, pie chart as well as in table format for discussion. Results were computed in arithmetic average $(\varnothing)$, standard deviation $( \pm)$, and weighting $(\%)$.

\section{RESULTS AND DISCUSSION}

\section{Survey respondents}

Following the arrangement we had earlier with the esurvey admin, the survey was brought to completion on May $16^{\text {th }}, 2020$. We received responses from 204 respondents as of May 16 $6^{\text {th }}, 2020$, which was the data cutoff collection date for this study.

\section{Socio-demographic factors}

The respondents were aged between 15-60 years; they were mapped out from different locations (Cities, Town, Villages, and others). There were 84 female respondents (41.2\%) and 120 male respondents (58.8\%). The majority of the respondents were students (36.5\%) and 
unemployed youth (16.8\%). The majority (49.5\%) were living in town as at the time the survey was conducted, the region with the highest reported cases of COVID-19 infection (Nigeria Centre for Disease Control, 2020). Similarly, 120 respondents (59.1\%) were between the age of $26-35,44$ respondents (21.7\%) were between the age of 18-25, 27 respondents (13.3\%) were between the age of 36 49,10 respondents $(4.9 \%)$ were below 18,3 respondents $(1.5 \%)$ were between the age of 50-60 years, and 1 respondent $(0.5 \%)$ refuse to answer. No individual of age above 60 years participated in the survey. The sociodemographic factors data such as gender, age, and place of residence are completely visualized in Figure 1 to Figure 3.

The result on participant's age suggests that individuals between the ages of 26-35 (usually tagged as youthful age) are more informed of the COVID-19 pandemic and are said to use social media more than individuals of the other age grades (Ahmad \& Murad, 2020). This is followed by individuals between the age grade of 18-25, $36-49$, as well as individuals below the age of 18 . The higher social media activity amongst teenagers and young adults over the older ones have been greatly documented since the advent of the information age (Shapiro \& Margolin, 2014; Lenhart et al., 2010).

Concerning the participant's place of residence, 101 respondents representing $49.5 \%$ live in town, 81 respondents $(39.7 \%)$ live in the city, 17 respondents $(8.3 \%)$ in the village, while 5 respondents (2.5\%) indicated they live in other places. This indicates that many people especially those in town are aware of the pandemic and its impending consequences (Garfin et al., 2020). This is because most likely they have access to electricity, as well as social media gadgets that require the use of networks. Also, they are more exposed to seeing the reality of practical cases as most isolation centers are located in towns (Nigeria Centre for Disease Control, 2020).

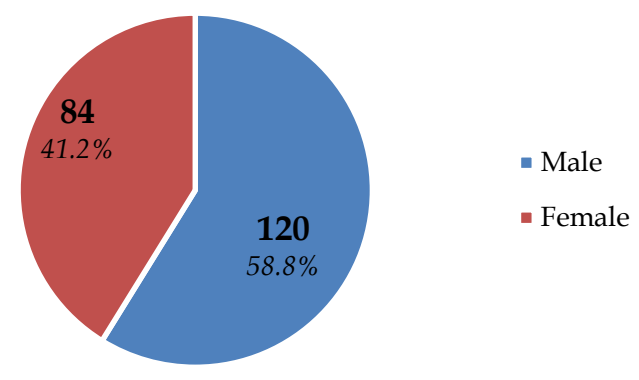

Figure 1. Gender comparison of respondents

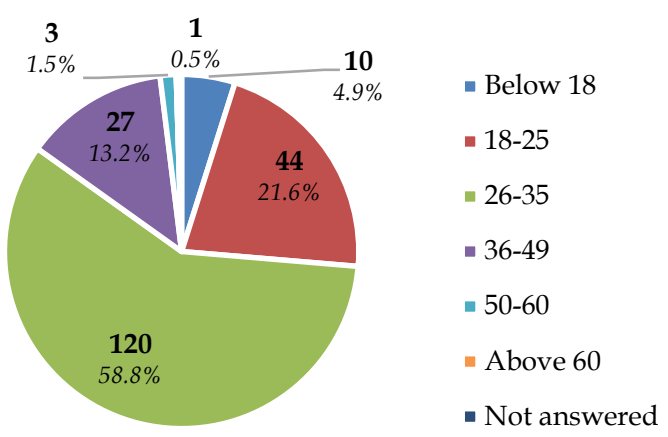

Figure 2. Age comparison of respondents

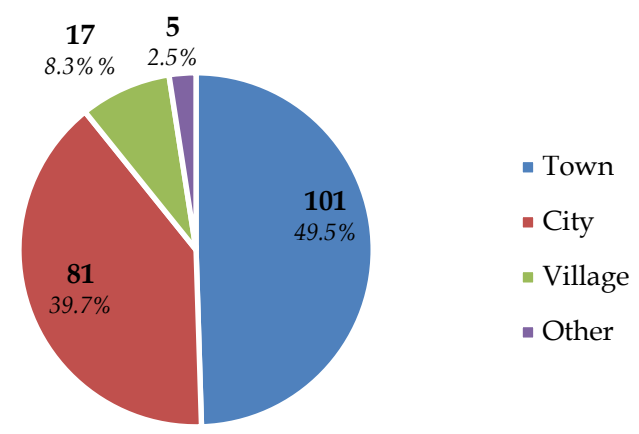

Figure 3. Place of residence comparison of respondents

A total of 24 respondents (12.2\%) are civil servants, 29 respondents (14.7\%) are entrepreneurs, 72 respondents $(36.5 \%)$ are students, 5 respondents $(2.5 \%)$ are military/paramilitary, 33 respondents $(16.8 \%)$ are unemployed, 34 respondents (17.3\%) indicated other occupations other than ones mentioned above, and 7 respondents $(3.4 \%)$ refuse to answered. Some other occupations reported include teachers, part-time civil servants, bankers, corporation members, and applicants. This showed that the students responded more to the 
idea of COVID-19 probably as a result of their quest for knowledge of this trending pandemic (Jribi et al., 2020). Among them, 78 respondents (39.4\%) said they use Facebook, 111 respondents (56.1\%) use WhatsApp, while only 1 respondent $(0.5 \%)$ indicated using other social media other than the aforementioned ones. The high rate of the use of Whatsapp social media could be attributed to its ease or less charge in terms of data usage, accessing, sharing, and/or reading news and information, especially those relating to the COVID-19 global pandemic (Dubey et al., 2020). The occupation as well as the type of social media most often used by the various respondents that participated in the survey are completely visualized in Figure 4 and Figure 5.

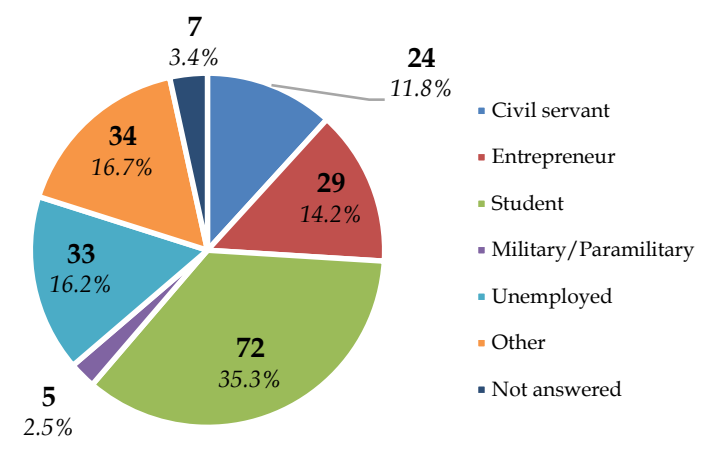

Figure 4. Occupation comparison of respondents

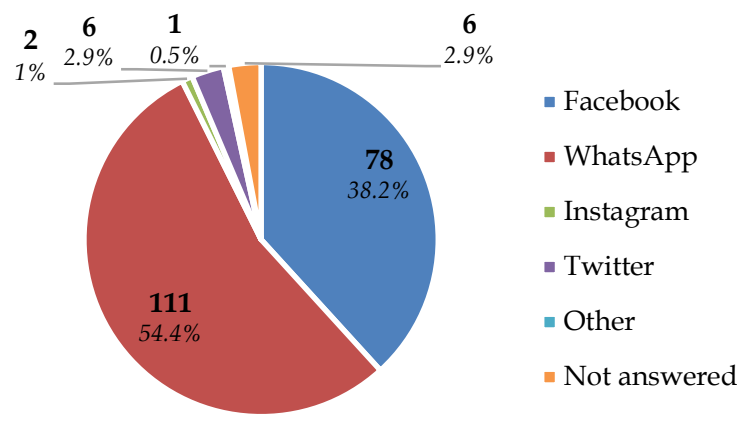

Figure 5. Social media usage comparison of respondents

The majority of respondents $(76.3 \%)$ were single, in line with the age of the majority of respondents aged 18-35 years. While the average personal income is mostly in the range below 20,000 Naira (equivalent to 50 USD) per month with 66 respondents (37.1\%). The average amount of income is directly related to the occupation of the respondents, the majority of which are students who still have no income. Results from showed that majority (76.3\%) of the respondent are not married with 33 respondents (16.8\%) unemployed even as the majority of the 66 respondents (37.1\%) earn below 20,000 nairas. The marital status and personal income of respondents that participated in the survey are completely visualized in Figure 6 and Figure 7.

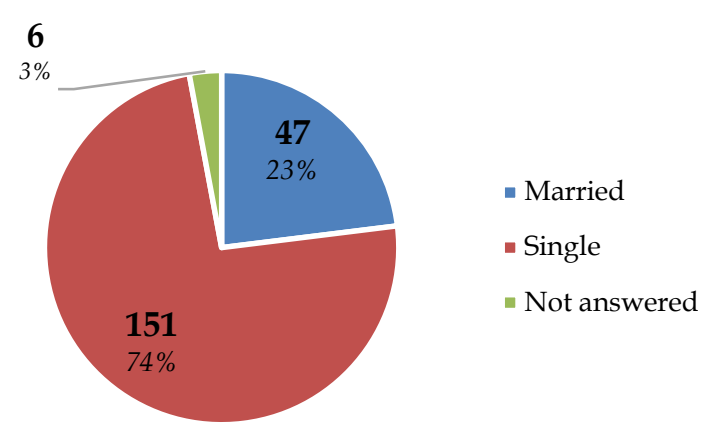

Figure 6. Marital status comparison of respondents

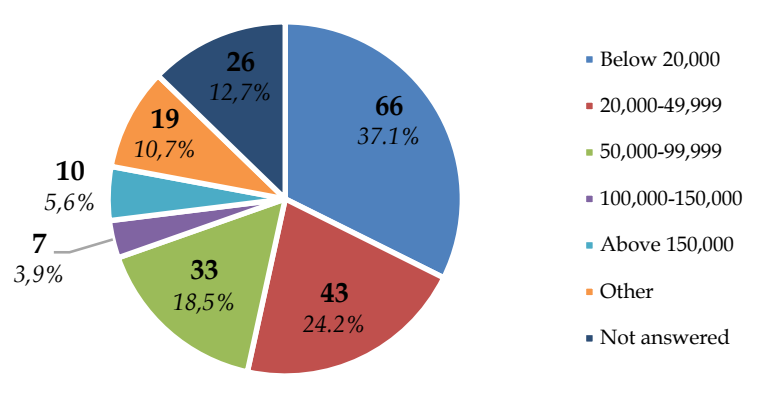

Figure 7. Personal income (Naira) comparison of respondents

The results of the analysis of respondents' answers regarding the respondent's perception of knowledge, attitude, and practice on the COVID-19 pandemic among Nigerians are presented in Figure 8. The results obtained vary, but there are some interesting question points because they provide relatively consistent answers among respondents. In particular, some negative statements related to COVID-19 that received a lot of disagreement by respondents. 


\begin{tabular}{|c|c|c|c|c|c|c|c|c|c|c|c|c|c|}
\hline & & $\begin{array}{l}\text { lot } \\
\text { reed } \\
\text { (1) }\end{array}$ & & $\begin{array}{l}\text { arely } \\
\text { reed } \\
\text { (2) }\end{array}$ & & $\begin{array}{l}\text { reed } \\
\text { (3) }\end{array}$ & & $\begin{array}{l}\text { ongly } \\
\text { reed } \\
\text { (4) }\end{array}$ & & $\begin{array}{l}5 . \\
\text { lumn } \\
\text { (5) }\end{array}$ & $\begin{array}{c}\text { no } \\
\text { answer } \\
(0)\end{array}$ & & \\
\hline & $\Sigma$ & $\%$ & $\Sigma$ & $\%$ & $\Sigma$ & & $\Sigma$ & $\%$ & $\Sigma$ & $\%$ & $\Sigma$ & $\emptyset$ & W \\
\hline Covid- 19 is a disease with... & $62 x$ & 34.44 & $30 x$ & 16.67 & $59 x$ & 32.78 & $28 x$ & 15.56 & - & - & $1 \mathrm{x}$ & 2.30 & $1.1060 \%$ \\
\hline Covid-19 is caused by the... & $29 x$ & 16.38 & $19 x$ & 10.73 & $84 x$ & 47.46 & $45 x$ & 25.42 & - & - & - & 2.82 & $20.9969 \%$ \\
\hline A healthy looking person c... & $153 x$ & 86.93 & $10 x$ & 5.68 & $7 x$ & 3.98 & $6 x$ & 3.41 & - & $\cdot$ & - & 1.24 & $40.6849 \%$ \\
\hline People may be sick for $1-1 \ldots$ & $41 x$ & 23.16 & $27 x$ & 15.25 & $77 x$ & 43.50 & $32 x$ & 18.08 & - & - & - & 2.56 & $31.0461 \%$ \\
\hline The transmission can be th.. & $8 x$ & 4.52 & $3 x$ & 1.69 & $83 x$ & 46.89 & $82 x$ & 46.33 & - & - & $1 \mathrm{x}$ & 3.36 & $0.7378 \%$ \\
\hline The virus doesn't penetrate.. & $38 x$ & 21.59 & $27 x$ & 15.34 & $76 x$ & 43.18 & $35 x$ & 19.89 & - & - & - & 2.61 & $1.0468 \%$ \\
\hline Older and sick people are ... & $14 x$ & 7.95 & $13 x$ & 7.39 & $69 x$ & 39.20 & $80 x$ & 45.45 & - & - & - & 3.22 & $0.9078 \%$ \\
\hline Most common symptoms m.. & $2 x$ & 1.14 & $6 x$ & 3.41 & $67 x$ & 38.07 & $99 x$ & 56.25 & $1 x$ & 0.57 & $1 \mathrm{x}$ & 3.52 & $0.6382 \%$ \\
\hline Prevention of the disease ... & $4 x$ & 2.27 & $6 x$ & 3.41 & $67 x$ & 38.07 & $98 x$ & 55.68 & - & - & $1 x$ & 3.48 & $30.6880 \%$ \\
\hline Covid-19 cannot be transm.. & $133 x$ & 75.57 & $13 x$ & 7.39 & $21 x$ & 11.93 & $9 x$ & 5.11 & - & - & - & 1.47 & $70.8945 \%$ \\
\hline Covid-19 is a punishment ... & $139 x$ & 78.98 & $17 x$ & 9.66 & $12 x$ & 6.82 & $7 x$ & 3.98 & $1 \mathrm{x}$ & 0.57 & - & 1.38 & $30.8339 \%$ \\
\hline The rate or the outbreak is... & $10 x$ & 5.68 & $10 x$ & 5.68 & $77 x$ & 43.75 & $78 x$ & 44.32 & $1 \mathrm{x}$ & 0.57 & - & 3.28 & $30.8278 \%$ \\
\hline The approach by the gove... & $79 x$ & 44.89 & $55 x$ & 31.25 & $34 x$ & 19.32 & $8 x$ & 4.55 & - & - & - & 1.84 & $0.9048 \%$ \\
\hline How would you agree with... & $31 x$ & 17.71 & $73 x$ & 41.71 & $53 x$ & 30.29 & $16 x$ & 9.14 & $1 x$ & 0.57 & $1 \mathrm{x}$ & 2.33 & $30.8952 \%$ \\
\hline More research towards a p... & $2 x$ & 1.13 & $3 x$ & 1.69 & $68 x$ & 38.42 & $101 x$ & 57.06 & $2 x$ & 1.13 & $1 \mathrm{x}$ & 3.56 & $0.6181 \%$ \\
\hline If they were some vaccine.... & $23 x$ & 12.92 & $29 x$ & 16.29 & $71 x$ & 39.89 & $50 x$ & 28.09 & $4 x$ & 2.25 & $1 x$ & 2.90 & $1.0366 \%$ \\
\hline
\end{tabular}

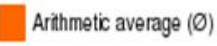

Standard deviation $( \pm)$

Weighting (\%)

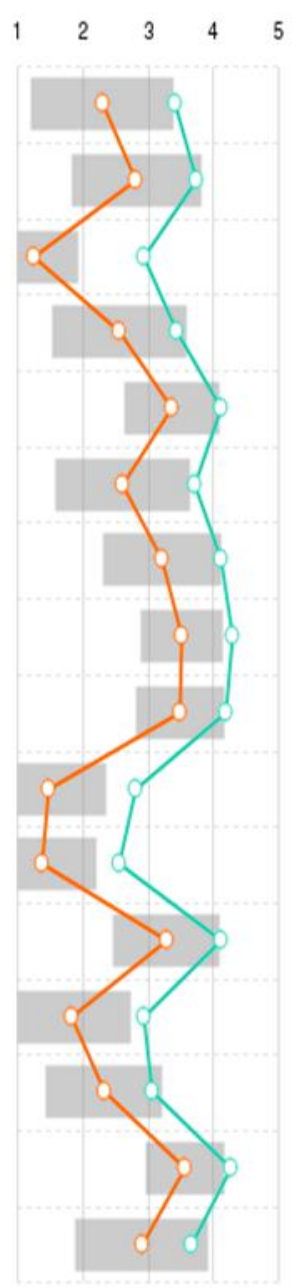

Figure 8. Respondent's perception of the knowledge, attitude, and practice on COVID-19 pandemic among Nigerians

Among them was a statement stating that healthylooking people who cannot contract the disease were approved by only $13 \%$ of respondents. Also, $76.83 \%$ of respondents agreed that COVID-19 sufferers might get sick for 1-14 days without developing typical symptoms. On the theme related to SARS-CoV-2 virus transmission, $94.41 \%$ of respondents agreed that transmission of the virus could be through direct contact with contaminated surfaces through the eyes, nose, and mouth. Besides, $78.35 \%$ of respondents stated that the SARS-CoV-2 virus did not penetrate the skin.

More than $92.04 \%$ of respondents agreed that older people and those who were sick were more susceptible to COVID-19, with $98.86 \%$ of respondents indicating that the most common symptoms included fever, fatigue, dry cough, and sometimes difficulty breathing. This is not like the report of Wolf et al. (2020) which shows that almost one-third of people cannot correctly identify symptoms (28.3\%) or ways to prevent infection (30.2\%). Furthermore, related to disease prevention, $97.73 \%$ of respondents agreed that prevention could include the use of face masks, washing hands, social distance, and self-isolation. However, only $24.43 \%$ of respondents stated that COVID-19 could not be transmitted through social gatherings, often occurring, making direct physical contact with people. Meanwhile, only $21.02 \%$ of 
respondents agreed that COVID-19 is a punishment for immoral behavior. This implies that respondents have a good level of knowledge and good practice about COVID-19 as reported by Chen et al. (2020). This could be one possible reason while the rate of spread of infection in this region is relatively restrained compared to that reported in the West.

At the epidemic level, $94.32 \%$ of respondents said that it was scary. This is consistent with Huynh (2020) who reported that among Vietnamese, respondents were more worried about the risk of contracting and being infected from COVID-19, with responses shown to be higher than the midpoint on the 10-point Likert Scale (t$\mathrm{stat}=28.94, \mathrm{p}<0.001)$. Du et al. (2020) also reported highlevel anxiety with the perceived need for mental health care for more than $80 \%$ of their participants. This shows the need for awareness of mental health care when a pandemic occurs.

Only $55.11 \%$ of respondents agreed that the approach by the Nigerian government in controlling outbreaks was satisfactory. This figure is lower than the $71.1 \%$ reported by Chen et al. (2020), which shows the need for a more humanitarian and fair response by the authorities in controlling a pandemic. However, $82.29 \%$ of the respondents agreed with the mass response to the government's move to control the spread, especially immediate actions.

In the future, $98.87 \%$ of respondents suggested that further research into a possible cure, control, or prevention be done, while $87.08 \%$ of the respondents agreed with the use of vaccination against the disease. Based on arithmetic weight and average scores, responses to the need for research rankings are followed by responses to outbreak scarcity. However, the response to "a person who appears healthy cannot contract the disease" ranks lowest compared to other statements.

\section{CONCLUSION}

Findings show that large portions of the study participant are aware and knowledgeable about COVID-19 and its presence in Nigeria. Results obtained from the research questions regarding knowledge of COVID-19 in terms of respondents' knowledge of the source, transmission, symptoms, preventive behavior, the fatality rate of the COVID-19, and the major resources of information about COVID-19 among north-central Nigerians were significantly high. A large portion of the study participant is scared of the COVID-19 pandemic and its outbreak in Nigeria this may be a result of the high rate of a fatality caused by this pandemic worldwide. This could imply that the respondents apprehend about COVID-19. The knowledge on COVID-19 could, therefore, support a better capacity to adopt precautionary measures leading to the control of the disease as was in the case of ebola.

\section{ACKNOWLEDGMENT}

We hereby acknowledge the contribution of all respondents who voluntarily answered the equestionnaire. An appreciation also goes to Mr. Gideon Oche Ehoche for referring to the online survey application used.

\section{REFERENCES}

Ahmad, A.R. \& Murad, H.R. (2020). The Impact of Social Media on Panic During the COVID-19 Pandemic in Iraqi Kurdistan: Online Questionnaire Study. Journal of Medical Internet Research, 22(5), e19556. doi:10.2196/19556

Andersen, P.I., Ianevski, A., Lysvand, H., Vitkauskiene, A., Oksenych, V., Bjørås, M., Telling, K., Lutsar, I., Dampis, U., Irie, Y., Tenson, T., Kantele, A., \& Kainov, D.E. (2020). Discovery and Development of Safe-In-Man Broad-Spectrum Antiviral Agents. International Journal of Infectious Diseases, 93, 268-276. doi:10.1016/j.ijid.2020.02.018 
Bhagavathula, A.S., Aldhaleei, W.A., Rahmani, J., Mahabadi, M.A., \& Bandari, D.K. (2020). Knowledge and Perceptions of COVID-19 Among Health Care Workers: Cross-Sectional Study. JMIR Public Health Surveillance, 6(2), e19160. doi:10.2196/19160

Chen, Y., Jin, Y.L., Zhu, L.J., Fang, Z.M., Wu, N., Du, M.X., Jiang, M.M., Wang, J., \& Yao, Y.S. (2020). [The Network Investigation on Knowledge, Attitude and Practice About Novel Coronavirus Pneumonia of the Residents in Anhui Province]. Zhonghua Yu Fang Yi Xue Za Zhi, 54(0), E004. doi:10.3760/cma.j.issn.02539624.2020.0004

Djalante, R., Lassa, J., Setiamarga, D., Sudjatma, A., Indrawan, M., Haryanto, B., Mahfud, C., Sinapoy, M.S., Djalante, S., Rafliana, I., Gunawan, L.A., Surtiari, G.A.K., \& Warsilah, H. (2020). Review and analysis of current responses to COVID-19 in Indonesia: Period of January to March 2020. Progress in Disaster Science, 6, 100091. doi:10.1016/j.pdisas.2020.100091

Du, B., Qiu, H.B., Zhan, X., Wang, Y.S., Kang, H.Y.J., Li, X.Y., Wang, F., Sun, B., \& Tong, Z.H. (2020). [Pharmacotherapeutics for the New Coronavirus Pneumonia]. Zhonghua Jie He He $\mathrm{Hu} \quad \mathrm{Xi} \quad \mathrm{Za}$ Zhi, 43(3), 173-176. doi:10.3760/cma.j.issn.1001-0939.2020.03.005

Dubey, S., Biswas, P., Ghosh, R., Chatterjee, S., Dubey, M.J., Chatterjee, S., Lahiri, D., \& Lavie, C.J. (2020). Psychosocial impact of COVID-19. Diabetology and Metabolic Syndrome, [Epub ahead of print]. doi:10.1016/j.dsx.2020.05.035

Ebenhardt, J.N., Breuckmann, N.P., \& Eberhardt, C.S. (2020). Multi-Stage Group Testing Improves Efficiency of Large-Scale COVID-19Screening. Journal of Clinical Virology, 128, 104382. doi:10.1016/j.jcv.2020.104382

European Centre for Disease Prevention and Control. (2020). COVID-19 situation update for the EU/EEA and the UK, as of 20 May 2020. https:/ /www.ecdc.europa.eu/en/cases2019-ncov-eueea

Felsenstein, S., Herbert, J.A., McNamara, P.S., \& Hedrich, C.M. (2020). COVID-19: Immunology and treatment options. Clinical Immunology, 215, 108448.

doi: https://dx.doi.org/10.1016/j.clim.2020.10844 8

Garfin, D.R., Silver, R.C., \& Holman, E.A. (2020). The Novel Coronavirus (COVID-2019) Outbreak: Amplification of Public Health Consequences by Media Exposure. Health Psychology, 39(5), 355-357. doi:10.1037/hea0000875

Hafeez, A., Ahmad, S., Siddqui, S.A., Ahmad, M., \& Mishra, S. (2020). A Review of COVID-19 (Coronavirus Disease-2019) Diagnosis, Treatments and Prevention. Eurasian Journal of Medical Sciences and Oncology, 4(2), 116-125. doi:10.14744/ejmo.2020.90853

Huynh, T.L.D. (2020). The COVID-19 risk perception: A survey on socioeconomics and media attention. Economics Bulletin, 40(1), 758-764.

Jribi, S., Ismail, H.B., Doggui, D., \& Debbabi, H. (2020). COVID-19 virus outbreak lockdown: What impacts on household food wastage? Environment, Development and Sustainability, [Epub ahead of print], 1-17. doi:10.1007/s10668-020-00740-y

Laviano, A. (2020). Nutrition support in the time of SARS-CoV-2 (COVID-19). Nutrition, 74, 110834. doi:10.1016/j.nut.2020.110834

Lenhart, A., Purcell, K., Smith, A., \& Zickuhr, K. (2010). Social Media E Mobile Internet Use Among Teens and Young Adults. Washington, US: Pew Internet and American Life Project. http:/ / pewinternet.org/Reports/2010/Social -Media-and-Young-Adults.aspx

Li, H., Liu, S.M., Yu, X.H., Tang, S.L., \& Tang, C.K. (2020). Coronavirus disease 2019 (COVID-19): current status and future perspectives. International Journal of Antimicrobial Agents, 105951. doi:10.1016/j.ijantimicag.2020.105951

Nigeria Centre for Disease Control. (2020). COVID-19 Cases Tracking Dashboard for Nigeria. https://covid19.ncdc.gov.ng/gis/

Olapegba, Ayandele, O., Kolawole, S.O., Oguntayo, R., Gandi, J., Dangiwa, A.L., Ottu, I.F.A., \& Iorfa, S.K. (2020). COVID-19 Knowledge and Perceptions in Nigeria. PsyArXiv, Preprints, 118. doi:10.31234/osf.io/j356x

Richard, P. (2016). Ebola: How A People's Science Helped End an Epidemic. London, UK: Zed Books. 
Shapiro, L.A.S. \& Margolin, G. (2014). Growing Up Wired: Social Networking Sites and Adolescent Psychosocial Development. Clinical Child and Family Psychology Review, 17(1), 1-18. doi:10.1007/s10567-013-0135-1

Wolf, M.S., Serper, M., Opsasnick, L., O'Conor, R., Curtis, L.M., Benavente, J.Y., Wismer, G., Batio, S., Eifler, M., Zheng, P., Russell, A., Arvanitis, M., Ladner, D., Kwasny, M., Persell, S.D., Rowe, T., Linder, J.A., \& Bailey, S.C. (2020). Awareness, Attitudes, and Actions Related to COVID-19 Among Adults with Chronic Conditions at the Onset of the U.S. Outbreak: A Cross-sectional Survey. Annals of Internal Medicine, [Epub ahead of print], M20-1239. doi:10.7326/m201239

Worldometer. (2020). COVID-19 Coronavirus Pandemic. https://www.worldometers.info/coronaviru s/ 